\title{
Recognition of imperforate atrioventricular valves by two dimensional echocardiography
}

\author{
M L RIGBY, D G GIBSON, M C JOSEPH, J C R LINCOLN, E A SHINEBOURNE, D F SHORE, \\ R H ANDERSON \\ From the Departments of Paediatrics and Cardiology, Brompton Hospital, Cardiothoracic Institute, Fulham Road, \\ London
}

SUMMARY The majority of hearts in which selective right or left atrial angiography shows no direct communication between one atrium and a ventricular chamber are considered to be examples of atresia of the right or left atrioventricular valves. Most patients presenting with the clinical features of tricuspid atresia have an absent right atrioventricular connection, while those with features of mitral atresia and a normal aortic root frequently have an absent left atrioventricular connection. By studying 67 patients using two dimensional echocardiography we have identified 12 in whom there was an imperforate atrioventricular valve and not an absent atrioventricular connection. Thus, in 44 hearts with the angiographic features of tricuspid atresia, 36 had absence of the right atrioventricular connection and six had an imperforate right atrioventricular valve. In the latter, four were examples of atrioventricular concordance and two were univentricular hearts of left ventricular morphology in which the mode of atrioventricular connection was through one perforate and one imperforate valve. Similarly, 17 out of 23 cases of mitral atresia had absence of the left atrioventricular connection. The remaining six had an imperforate left atrioventricular valve which was associated with atrioventricular concordance in two patients and with double inlet univentricular hearts in four patients.

The majority of hearts with what is generally termed "tricuspid atresia" are examples of absent right atrioventricular connection. ${ }^{1-3}$ The cardinal anatomical feature is the absence of any potential communication between the floor of the right atrium and the ventricular mass, sulcus tissue interposing between them. In some cases, however, a similar clinical picture may emerge when there is an imperforate right atrioventricular valve. ${ }^{1-4}$ These hearts may be examples of atrioventricular concordance, atrioventricular discordance, or univentricular hearts. Similarly, isolated mitral atresia may be an example of either absent left atrioventricular connection or imperforate left atrioventricular valve. Mitral atresia is commonly associated with aortic valve atresia or severe aortic stenosis, and pronounced hypoplasia of the ascending yorta. This group of abnormalities is often associated with an imperforate mitral valve and is incompatible with life beyond the neonatal period. ${ }^{5}$ In mitral atresia with a normal aortic root, however, which carries a better prognosis, the type of atrioventricular connection is most commonly absent left connection.

Accepted for publication 3 December 1981
The hallmark of an imperforate valve is that it provides potential communication between an atrium and a ventricle. It exists as fused valve leaflets usually possessing their own hypoplastic tensor apparatus. The presence of an imperforate valve may have important surgical implications. For example, in hearts with atrial situs solitus and atrioventricular concordance, a valvotomy of an imperforate tricuspid valve may perhaps be preferable to a Fontan procedure.

In the past, diagnosis of this abnormality has been impossible clinically, and extremely difficult on angiography because of the similarities in the appearances of hearts with an absent atrioventricular connection. M-mode echocardiography alone is of some value in the demonstration of an imperforate valve, ${ }^{6}$ but two dimensional echocardiography, by providing detailed visualisation of the atrioventricular junction, would be expected to identify such an abnormality. It is for this reason that our study was undertaken.

\section{Patients and methods}

Forty-four patients with angiographic features of "tricuspid atresia" and 23 with features of "mitral 
atresia" (with a normal aortic root and ascending aorta) were studied by echocardiography. Their ages ranged from 1 day to 14 years and in each case absence of anterograde flow from an atrium had been demonstrated by angiography. Two dimensional echocardiograms were performed using an Advanced Technology Laboratories wide angled mechanical sector scanner. The examination was carried out in such a way as to show both the type and moae of atrioventricular connection using selected tomographic views of the heart. ${ }^{7}$ In the majority of cases, echocardiograms were recorded on a video display system which allowed repeated examination of the original real time images. Those hearts possessing an imperforate right or left atrioventricular valve were selected for inclusion in the study. Those with absent right or left atrioventricular connection were excluded.

\section{Results}

Two dimensional echocardiography showed the precise type and mode of atrioventricular connection in 65 of the 67 patients with tricuspid or mitral atresia. In 12 cases there was unequivocal evidence of an imperforate valve and these hearts are those included in the present study. Of the remainder, 53 hearts were considered to be examples of either absent left or absent right atrioventricular connection, though in eight cases the distinction between absent connection and thickened imperforate valve could not be made with certainty. Unsatisfactory echocardiograms were recorded in two patients.

\section{IMPERFORATE RIGHT ATRIOVENTRICULAR VALVE} (Table 1)

\section{(a) With atrioventricular concordance}

All the four hearts with atrioventricular concordance were characterised by having the right atrium separated from a hypoplastic right ventricle by an imperforate membrane (Fig. 1). The tensor apparatus of the valve could be seen only in two cases. In each of the four patients, the recognition of the small right sided hypoplastic right ventricle as one of right ventricular morphology was dependent upon identifying the septal portion of the imperforate valve dividing the ventricular septum into atrioventricular and interventricular parts (Fig. 1).
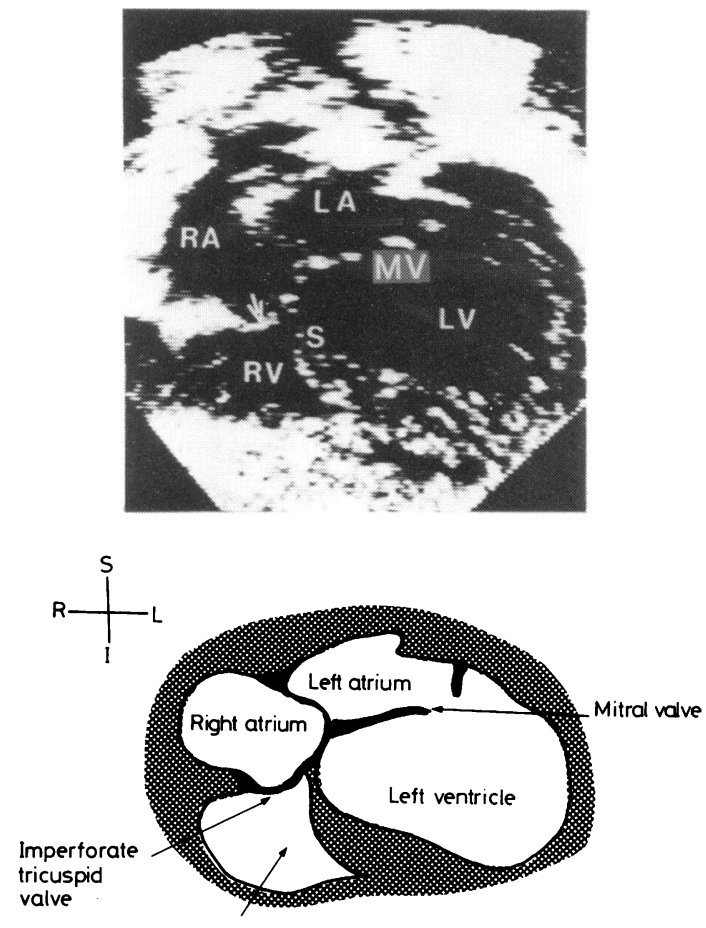

Right ventricle

Fig. 1 Subcostal view of a heart with atrioventricular concordance with an imperforate tricuspid valve (arrow). The right ventricle $(R V)$ is hypoplastic. The imperforate tricuspid valve divides the interventricular septum $(S)$ into atrioventricula and interventricular parts. $R A$, right atrium; $L A$, left atrium; $M V$, mitral valve; $L V$, left ventricle.

Table 1 Imperforate right atrioventricular valve

\begin{tabular}{|c|c|c|c|c|}
\hline Case No. & Atrial situs & $\begin{array}{l}\text { Type of atrioventricular } \\
\text { connection }\end{array}$ & $\begin{array}{l}\text { Ventriculoarterial } \\
\text { connection }\end{array}$ & Associated abnormalities \\
\hline 1 & Solitus & Concordant & Concordant & $\begin{array}{l}\text { Atrial septal defect, pulmonary valve } \\
\text { atresia }\end{array}$ \\
\hline 2 & Solitus & Concordant & Concordant & $\begin{array}{l}\text { Patent foramen ovale, pulmonary } \\
\text { atresia }\end{array}$ \\
\hline 3 & Solitus & Concordant & Concordant & $\begin{array}{l}\text { Patent foramen ovale, ventricular septal } \\
\text { defect, severe subpulmonary stenosis }\end{array}$ \\
\hline 4 & Solitus & Concordant & Concordant & $\begin{array}{l}\text { Atrial septal defect, ventricular septal } \\
\text { defect, pulmonary atresia }\end{array}$ \\
\hline $\begin{array}{l}5 \\
6\end{array}$ & $\begin{array}{l}\text { Solitus } \\
\text { Solitus }\end{array}$ & $\begin{array}{l}\text { Double inlet ventricle } \\
\text { Double inlet ventricle }\end{array}$ & $\begin{array}{l}\text { Concordant } \\
\text { Discordant }\end{array}$ & $\begin{array}{l}\text { Patent foramen ovale, pulmonary atresia } \\
\text { Atrial septal defect, pulmonary artery } \\
\text { banding }\end{array}$ \\
\hline
\end{tabular}

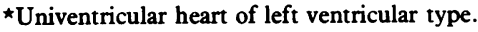


(b) With double inlet ventricle

In the two univentricular hearts with an imperforate right atrioventricular valve, the mode of atrioventricular connection was by one perforate and one imperforate valve (Fig. 2). An imperforate valve was seen as a thin membrane between the right atrium and the main left ventricular chamber, but in only one case was there unequivocal demonstration of tensor apparatus. The characteristic feature of these hearts was that the atrioventricular connections were posterior to the septum present in the ventricular mass; hence they were univentricular hearts of left ventricular morphology.

\section{IMPERFORATE LEFT ATRIOVENTRICULAR VALVE} (Table 2)

\section{(a) With atrioventricular concordance}

Two hearts with atrioventricular concordance had an imperforate membrane between the left atrium and a hypoplastic left ventricle. Tensor apparatus was identified in one of these (Fig. 3). The recognition of the small left sided ventricle as one of left ventricular morphology was based upon identifying its smooth trabecular pattern (Fig. 4). In both cases the septal leaflet of the perforate right atrioventricular valve divided the ventricular septum into atrioventricular and interventricular parts, confirming that the large right sided ventricle was of right ventricular morphology (Fig. 4).

(b) With double inlet ventricle

In each of the four univentricular hearts, the mode of atrioventricular connection was through a perforate right and an imperforate left atrioventricular valve. Rudimentary tensor apparatus was identified in two. The characteristic feature of the two univentricular hearts of right ventricular morphology was that the atrioventricular junction was anterior to the septum present in the ventricular mass, whereas in the two
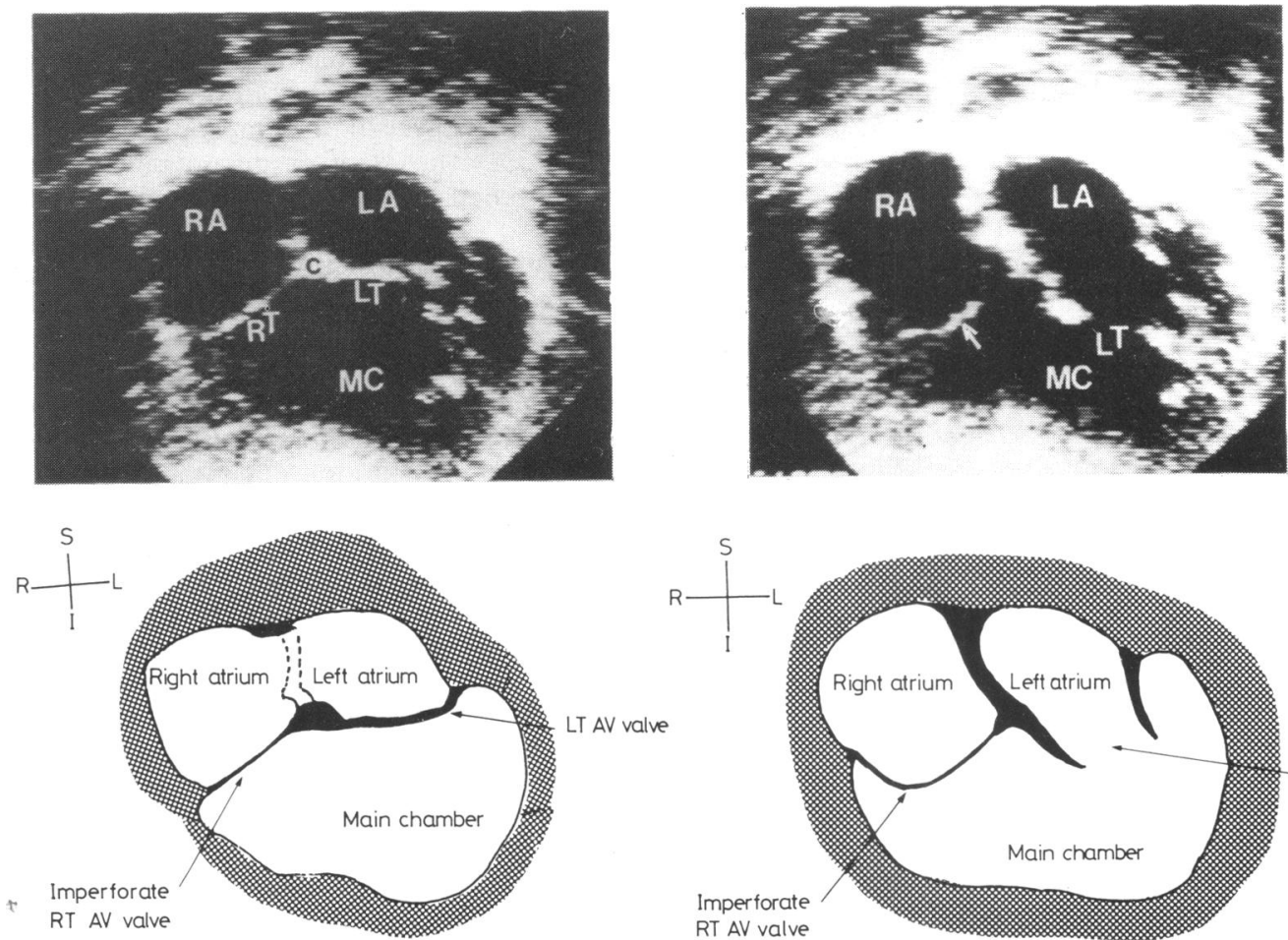

(a)

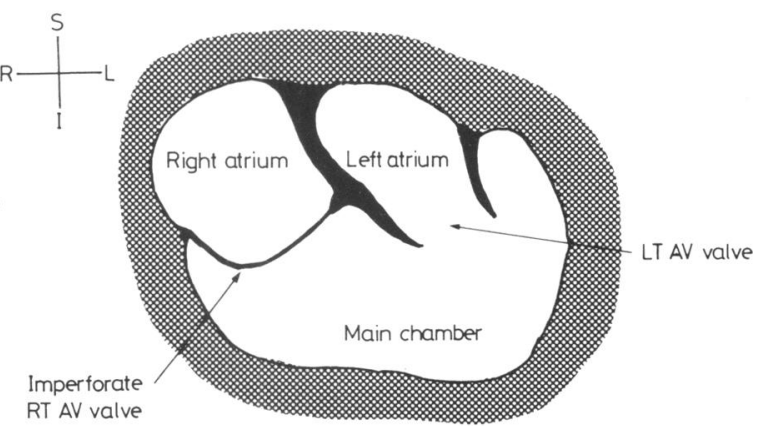

(b)

Fig. 2 (a) Apical view of double inlet univentricular heart taken in systole. There is an imperforate right atrioventricular valve (RT) and the left atrioventricular valve $(L T)$ is closed. $R A$, right atrium; $L A$, left atrium; $M C$, main chamber; $C$, central fibrous body. (b) Apical view of double inlet univentricular heart taken in diastole. The imperforate right atrioventricular valve is shown by an arrow and the left atrioventricular valve (LT) is open. 
Table 2 Imperforate left atrioventricular valve

\begin{tabular}{|c|c|c|c|c|}
\hline Case No. & Atrial situs & $\begin{array}{l}\text { Type of atrioventricular } \\
\text { connection }\end{array}$ & $\begin{array}{l}\text { Ventriculoarterial } \\
\text { connection }\end{array}$ & Associated abnormalities \\
\hline 7 & Solitus & Concordant & Concordant & $\begin{array}{l}\text { Atrial septal defect, ventricular septal } \\
\text { defect }\end{array}$ \\
\hline 8 & Solitus & Concordant & Concordant & $\begin{array}{l}\text { Patent foramen ovale, ventricular septal } \\
\text { defect }\end{array}$ \\
\hline 9 & Solitus & Double inlet ventricle* & Concordant & $\begin{array}{l}\text { Atrial septal defect, coarctation, } \\
\text { subpulmonary stenosis }\end{array}$ \\
\hline 10 & Solitus & Double inlet ventricle* & Concordant & $\begin{array}{l}\text { Atrial septal defect, cardiomyopathy, } \\
\text { subaortic stenosis }\end{array}$ \\
\hline 11 & Solitus & Double inlet ventricle† & Double outlet ventricle & $\begin{array}{l}\text { Atrial septal defect, pulmonary atresia, } \\
\text { partial anomalous pulmonary venous } \\
\text { drainage }\end{array}$ \\
\hline 12 & Solitus & Double inlet ventriclet & Double outlet ventricle & $\begin{array}{l}\text { Atrial septal defect, subpulmonary } \\
\text { stenosis }\end{array}$ \\
\hline
\end{tabular}

^Univentricular heart of right ventricular type.

†Univentricular heart of indeterminate type.

univentricular hearts of indeterminate morphology it was not possible to identify a second chamber within the ventricular mass.

\section{PROBLEM CASES}

In eight cases, five with tricuspid atresia and three with mitral atresia, the distinction between absent atrioventricular connection and an imperforate valve was difficult. In each case a thick echo, interposed between the floor of the atria and ventricle, could have been interpreted as either sulcus tissue or a thick imperforate valve (Fig. 5). Unless we have demonstrated a thin membrane or the tensor apparatus we have considered the atrioventricular connection to be absent.

\section{Discussion}

The atrioventricular junction is that part of the heart where the atria connect to the ventricles. In the normal heart it is made up of two fibrous annuli which also support the leaflets of the atrioventricular valves. It is our practice to define the type of atrioventricular connection as the way the atria are connected, via the fibrous annuli, to the ventricles. We refer to the morphology of the valves which guard the atrioventricular junction as the mode of atrioventricular connection. ${ }^{2} 3$

In hearts with two ventricles the type of atrioventricular connection may be concordant, discordant, or ambiguous, the latter being applicable when the atria themselves are isomeric. ${ }^{8}$ In a univentricular heart, which we define as any heart in which only one ventricular chamber possesses an atrioventricular connection or connections, the type of atrioventricular connection may be double inlet (both atria connecting to one ventricle), absent right, or absent left connection. ${ }^{910}$ When both atria have a direct connection to the ventricular mass, the mode of atrioventricular connection may be via two discrete valves or by a common valve. When two valves are present, one of them may be imperforate or may override or straddle a septum.

In hearts with an imperforate right atrioventricular valve, the clinical presentation may be identical to classical tricuspid atresia (absent right connection) and similarly an imperforate left atrioventricular valve can be indistinguishable, from the clinical standpoint, from isolated absence of the left atrioventricular connection. ${ }^{11}$ This is true if the imperforate valve is associated with concordant or discordant atrioventricular connections or with double inlet univentricular heart.

Imperforate right atrioventricular valves have been described by several authors, albeit in most instances briefly. ${ }^{1412-14}$ There have been two descriptions associated with Ebstein's anomaly. 1516 The features of an imperforate left atrioventricular valve have been mentioned by some authors without complete descriptions. ${ }^{11} 12$ In contrast, others have failed to acknowledge the distinction between an absent connection and an imperforate valve in detailed accounts of tricuspid atresia, mitral atresia, or univentricular hearts. ${ }^{17-19}$ We have described the two dimensional echocardiographic features of imperforate valves in 12 patients and have included not only hearts with atrioventricular concordance but also those with double inlet univentricular hearts. There appear to be no detailed published accounts of the latter. It is conceivable that hearts exist with an imperforate left or right atrioventricular valve in which the type of atrioventricular connection is discordant but we have not discovered any.

In the past, the diagnosis of an imperforate valve was of little clinical significance and could be made with certainty only at necropsy. We have previously described the two dimensional echocardiographic features of univentricular hearts, including those with absent right or left atrioventricular connections. ${ }^{9}$ This 

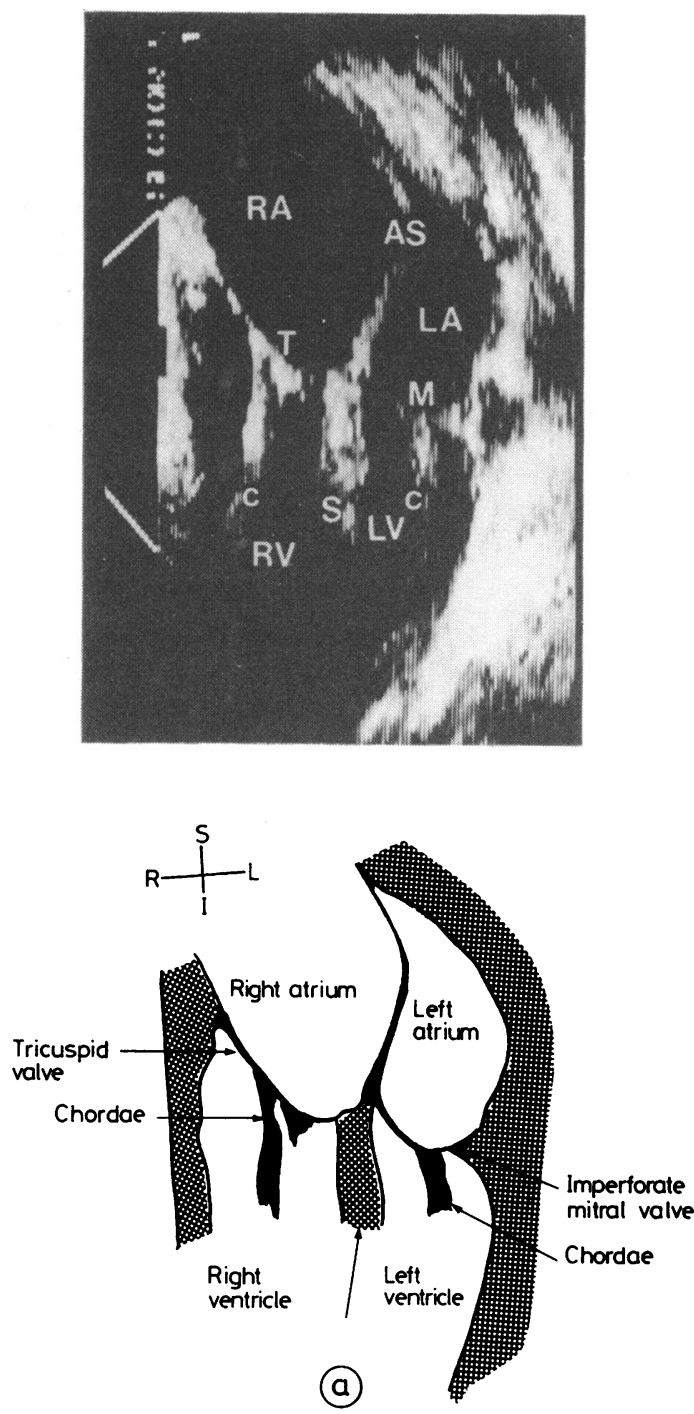
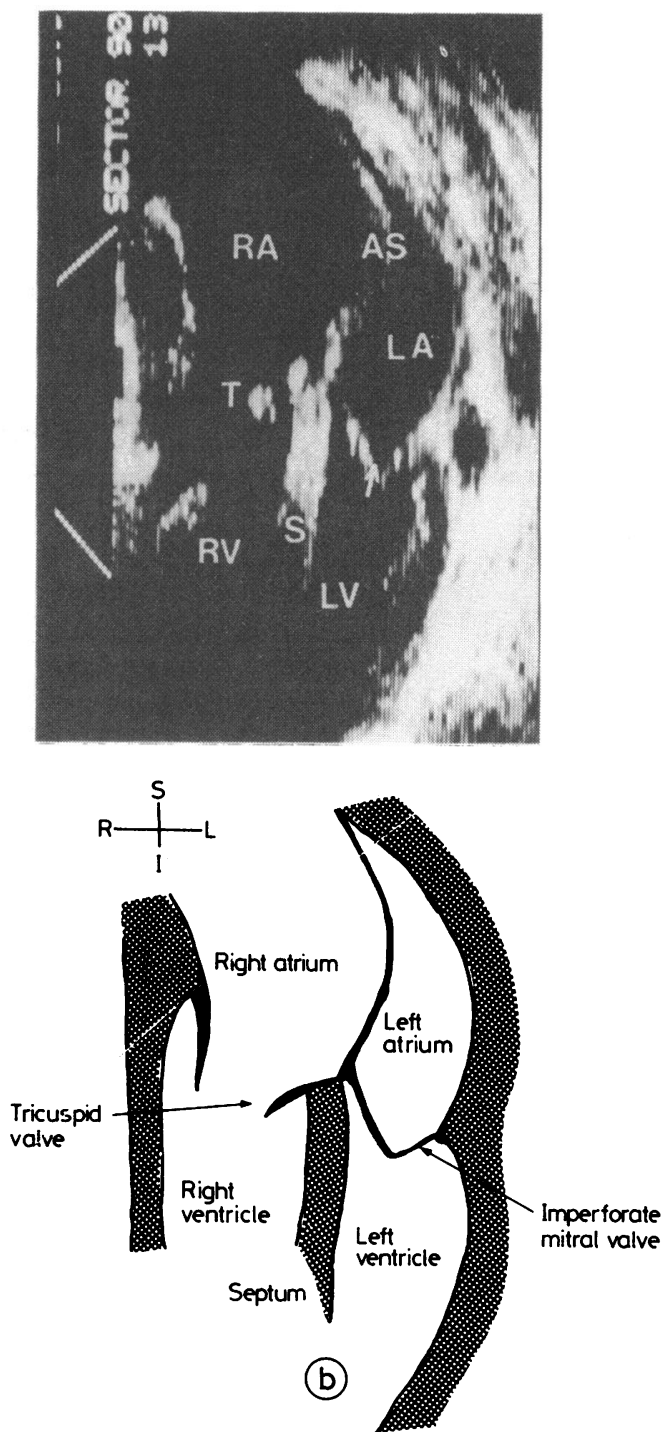

(b)

$(R A)$ is divided from the small left atrium $(L A)$ by the atrial septum $(A S)$. The tensor apparatus $(C)$ of the tricuspid valve $(T)$ is clearly seen in the right ventricle $(R V)$. The tensor apparatus $(C)$ of the imperforate mitral valve $(M)$ is clearly seen in the left ventricle $(L V)$. S, interventricular septum. (b) Subcostal view of the same heart recorded during diastole. The tricuspid valve (T) is open. The mitral valve (arrow) remains closed because it is imperforate.

study has shown that two dimensional echocardiography permits accurate assessment of the atrioventricular junction when the mode of connection is through one perforate and one imperforate valve. Moreover, hearts with atrioventricular concordance or discordance can be distinguished from univentricular hearts with double inlet connection. The cornerstone of the diagnosis of an imperforate valve is the identification of a thin mobile membrane between an atrium and a ventricle and the recognition of the tensor apparatus of the valve. In the majority of cases the tensor apparatus is hypoplastic and therefore its delineation by echocardiography is not always possible. Indeed it may not be discovered at necropsy. In some instances the imperforate membrane may be thickened, then, without the demonstration of the tensor apparatus, an 

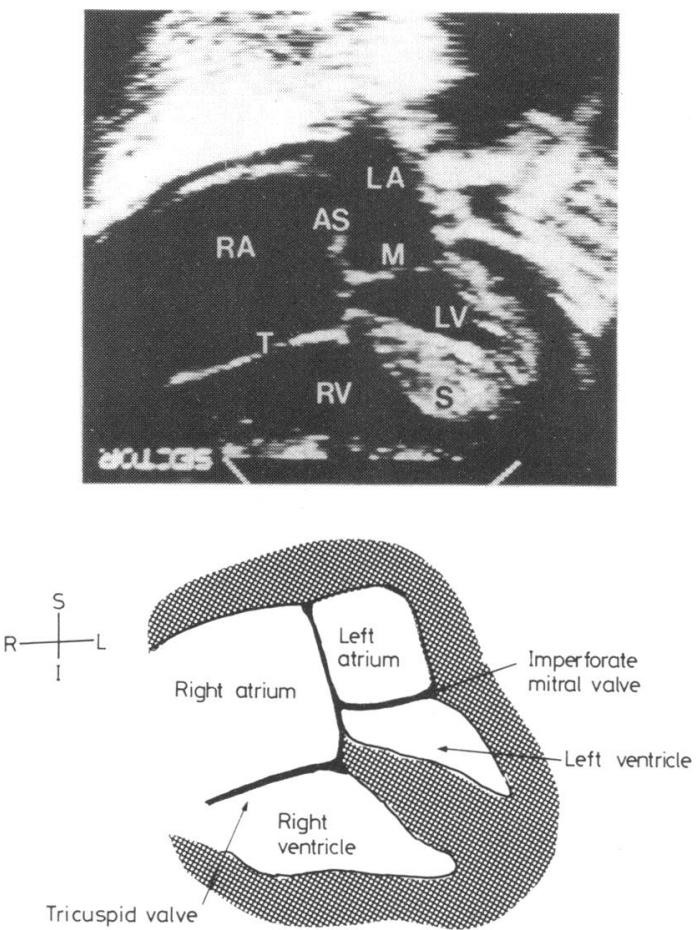

Fig. 4 Apical view of the same heart shown in Fig. $3 a$ and $3 b$. This frame is taken during systole and shows that the septal leaflet of the tricuspid valve $(T)$ divides the interventricular septum into atrioventricular and interventricular parts because the tricuspid is attached further towards the apex than the mitral valve. The left atrium $(L A)$ and left ventricle $(L V)$ are relatively hypoplastic. $S$, interventricular septum; $R A$, right atrium; $R V$, right ventricle.

unequivocal diagnosis of imperforate valve cannot be made. It seems likely, therefore, that we have occasionally failed to recognise some examples, but nevertheless an accurate demonstration of the mode of atrioventricular connection is possible in the majority of cases.

We are unaware of any other description of the two dimensional echocardiographic appearances of imperforate valves, though recognition by combining angiographic appearances and $M$-mode echocardiography has been reported. ${ }^{6}$ In four of our patients, two with an imperforate right and two with an imperforate left atrioventricular valve, the M-mode echocardiogram disclosed the features of double inlet univentricular heart with two atrioventricular valves, though in each case selective atrial angiography has shown only one perforate valve. It seems therefore that ballooning of an imperforate valve into the ventricle during diastole mimicked the $\mathrm{M}$-mode echocardiographic features of a perforate valve (Fig. 6).

The clinical presentation of absent right or left
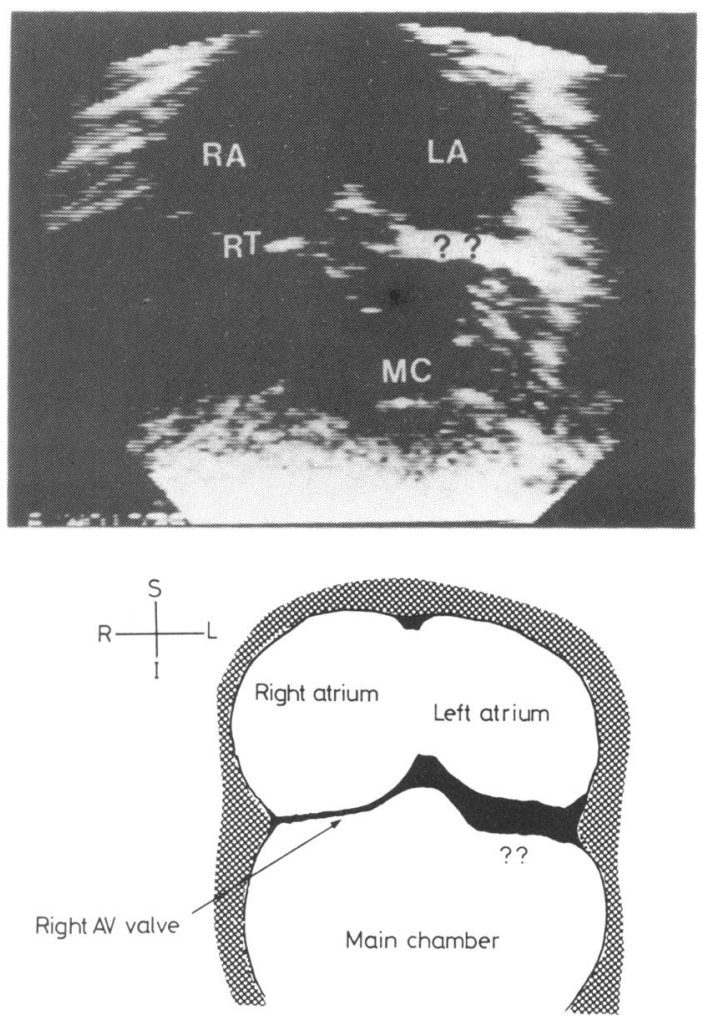

Fig. 5 Apical view of a univentricular heart in which differentiation of absent left atrioventricular connection from an imperforate left atrioventricular valve was difficult. There appears to be potential communication between the left atrium $(L A)$ and the main chamber $(M C)$ through a thick membrane (??). This could be either sulcus tissue or a thickened imperforate valve. No tensor apparatus is seen and this is considered to be an example of absent left connection. $R A$, right atrium; $R T$, right atrioventricular valve.

atrioventricular connection can be mimicked not only by an imperforate valve but also by severe stenosis of the right or left atrioventricular valve, respectively. In some of these cases selective atrial angiography, or for that matter contrast echocardiograms, should distinguish severe stenosis from an imperforate membrane. One of our patients was thought to have atrioventricular concordance with an imperforate tricuspid valve, using both two dimensional echocardiographic and angiographic criteria, and underwent successful tricuspid valvotomy. At operation, however, a very small tricuspid valve orifice was found though the valve appeared to be functionally imperforate. From the clinical standpoint, distinction between a truly imperforate valve and severe stenosis may be impossible.

With the demonstration by Fontan and Baudet that radical palliative surgery is possible for classical 


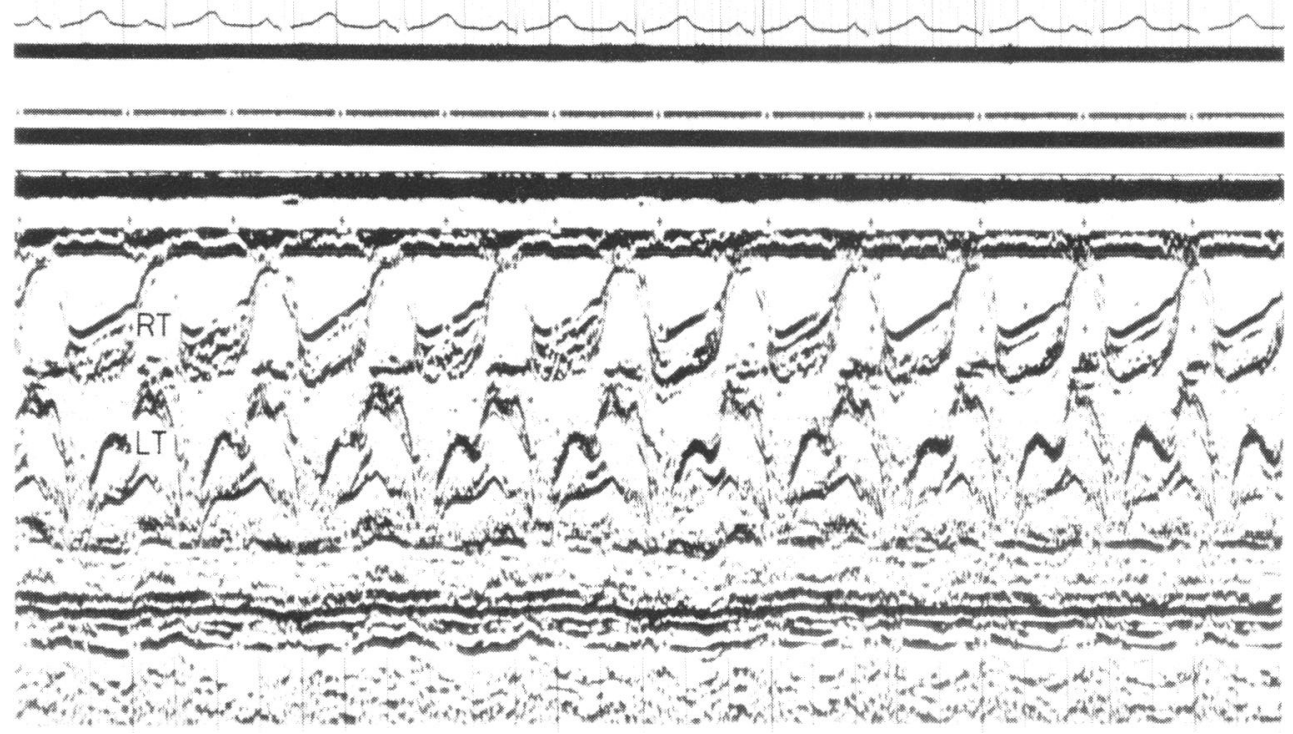

Fig. 6 M-mode echocardiogram of a double inlet univentricular heart with an imperforate right atrioventricular valve $(R T)$. The appearances are of a double inlet univentricular heart with two perforate valves because there is diastolic apposition of the left atrioventricular valve $(L T)$ and the right atrioventricular valve. The two dimensional echocardiogram showed an imperforate right atrioventricular valve and this was confirmed by selective right atrial angiography.

tricuspid atresia, ${ }^{20}$ accurate description of the anatomy of the atrioventricular junction has become essential. It is evident from our own experience that hearts with atrioventricular concordance and an imperforate tricuspid valve can in some cases be managed by tricuspid valvotomy rather than by a Fontan procedure. If the imperforate valve is hypoplastic, however, or lacks any tensor apparatus the latter may be preferable.

Our study has shown the value of two dimensional echocardiography in the diagnosis of patients in whom the mode of atrioventricular connection is through one perforate and one imperforate valve. We have shown that in these hearts the distinction between atrioventricular concordance and double inlet univentricular heart can be readily made. It must be emphasised that while the majority of patients presenting with tricuspid or mitral atresia will have absence of the right or left atrioventricular connection, respectively, a small number will have an imperforate valve, the identification of which may alter the surgical options available.

\section{References}

1 Anderson RH, Wilkinson JL, Gerlis ML, Smith A, Becker AE. Atresia of the right atrioventricular orifice. Br Heart F 1977; 39: 414-28.
2 Shinebourne EA, Macartney FJ, Anderson RH. Sequential chamber localization- logical approach to diagnosis in congenital heart disease. Br Heart F 1976; 38: 327-40.

3 Tynan MJ, Becker AE, Macartney FJ, Quero Jimenez M, Shinebourne EA, Anderson RH. The nomenclature and classification of congenital heart disease. Br Heart $\mathcal{F}$ 1979; 41: 544-53.

4 Dickinson DF, Wilkinson JL, Smith A, Anderson RH. Atresia of the right atrioventricular orifice with atrioventricular concordance. Br Heart f 1979; 42: 9-14.

5 Friedman S, Murphy L, Ash R. Congenital mitral atresia with hypoplastic non-functioning left heart. Am $\mathcal{F}$ Dis Child 1955; 90: 176-88.

6 Anderson RH, Beardshaw JA, Gibson DG. Echocardiography of primitive ventricle and corrected transposition. In: Lundstrom NR, ed. Echocardiography in congenital heart disease. Amsterdam: Elsevier/NorthHolland Biomedical Press, 1979: 229-51.

7 Tajik AJ, Seward JB, Hagler DJ, Mair DD, Lie JT. Two-dimensional real time ultrasonic imaging of the heart and great vessels. Mayo Clin Proc 1978; 43: 271303.

8 Macartney FJ, Zuberbuhller JR, Anderson RH. Morphological considerations pertaining to recognition of atrial isomerism. Consequences for sequential chamber localisation. Br Heart $\mathcal{F}$ 1980; 44: 657-67.

9 Rigby ML, Anderson RH, Gibson D, Jones ODH, Joseph MC, Shinebourne EA. Two-dimensional echocardiographic categorisation of the univentricular heart: ventricular morphology, type and mode of atrioventricular connection. Br Heart f 1981; 46: 603-12. 
10 Wilkinson JL, Becker AE, Tynan M, et al. Nomenclature of the univentricular heart. Herz 1979; 4: 107-12.

11 Summerell J, Miller C, Persaud V, Talerman A. Congenital mitral atresia. Br Heart f 1968; 30: 249-54.

12 Moreno F, Quero JM, Diaz LP. Mitral atresia with normal aortic valve. A study of eighteen cases and a review of the literature. Circulation 1976; 53: 1004-10.

13 Quero-Jimenez M, Cameron AH, Acerate F, Quero Jiménez C. Univentricular hearts: pathology of the atrioventricular valves. Herz 1979; 4: 161-5.

14 Quero-Jiménez $M$, Maître Azcárate $M J$, Alvarez Bejarano H, Vázquez Martul E. Tricuspid atresia: an anatomical study of seventeen cases. Eur $\mathcal{f}$ Cardiol 1975; 3: $337-48$.

15 Gerlis LM, Anderson RH. Cor triatriatum dexter with imperforate Ebstein's anomaly. Br Heart $\mathcal{f}$ 1976; 38: 108-11.

16 Rao PS, Jue KL, Isabel-Jones J, Ruttenberg HD. Ebstein's malformation of the triscupid valve with atresia. Am F Cardiol 1973; 32: 1004-9.
17 Eliot RS, Shore JD, Kanjuh VI, Ruttenberg HD, Carey LS, Edwards JE. Mitral atresia: a study of 32 cases. Am Heart f 1965; 70: 6-22.

18 Tandon R, Edwards JE. Tricuspid atresia. A reevaluation and classification. $\mathcal{F}$ Thorac Cardiovasc Surg 1974; 67: 530-42.

19 Watson DG, Rowe RD, Conen PE, Duckworth JW. Mitral atresia with normal aortic valve. Report of 11 cases and review of the literature. Pediatrics 1960; 25: 450-7.

20 Fontan F, Baudet E. Surgical repair of tricuspid atresia. Thorax 1971; 26: 240-8.

Requests for reprints to Dr M L Rigby, Department of Paediatrics, Brompton Hospital, Fulham Road, London SW3 6HP. 